\title{
The Study of Switch Socket Waste Problem in Family Decoration
}

\author{
Ai Lina \\ Department of politics \\ North China Electric Power University \\ BaoDing China \\ 1069273727@qq.com
}

\author{
JIan Tiegu \\ Department of politics \\ North China Electric Power University \\ BaoDing China \\ jxqq12@qq.com
}

\begin{abstract}
This article mainly from the waste of decorating family, switch socket is emphatically discussed. In this paper, we use qualitative and quantitative research method of combining the switches and sockets for home improvement wasteful conduct research. From the current situation of urban families decorating switch socket, analysis the reasons for this waste phenomenon from the angle of ideological level, developers, technological level and the policy of our country law blind spots. In addition, we concluded that we need through policy formulation, such as publicity and education to enhance people's environmental protection concept, make people use practical actions to reduce the waste of switch socket.
\end{abstract}

Keywords-Energy conservation; Socket Switch; Waste; Solutions; Significance

\section{THE STSTUS QUE}

House decoration is often a waste of subtle overlooked, especially the switch socket wastage. Taking a relatively modest price of power switches and sockets as standard, power switches and sockets in every 6 to 8 yuan, the average family in the need to replace the renovation of 40 to 60 , in addition to the burden on the economy of 240 to 480 yuan, but the replaced socket switch has not been recovered secondary use and reasonable reproduction, causing the waste of resources and polluting the environment. With more and more popular in recent years, real estate sales, the rapid increase in the number of housing transactions and trading area, a sharp increase in house needs renovation, and brought the socket switch and growing waste. For example, Shenyang decoration of record company has more than 1000 , a conservative estimate, the annual waste money on a replacement socket switch also more than 10 million yuan. But more serious than the more serious problem of waste receptacle switch is that people did not realize the presence of waste, without giving enough attention. We will analyze this problem as following:

\section{A. New home renovation waste resulting from changing the switch socket}

After the vast majority of people buy rough housing, the developers have already installed socket switch. The vast majority of households in the renovation after the purchase, will be in the majority or all of the socket switch replaced. The replaced switch socket becomes garbage, even though the vast majority of these switches can continue to use the socket.

\section{B. The waste of setting unreasonable switch socket}

Setting unreasonable switch socket consists of the following three aspects:

1) When the household purchasing rough room, decoration companies installing the switch socket is greater than the number of households demanding, which makes some socket switch did not play much part in the housing cycle, or simply did not play roles;

2) When households purchase rough housing, decoration companies was not on the location and relative distance socket switch installation planning, resulting in low utilization rate of the switch socket and high repetition waste. Such as a 100-square-meter house, if rational planning socket switch position requires 45 socket switch, which meet all the electricity needs of households, but because the plan is unreasonable, you need 48 to meet household needs, the extra 3 is the waste;

3) Household was not satisfied with the decoration companies' socket switch, including styles, materials, types, etc, which makes household change socket switch resulting in the waste.

\section{The waste of selecting socket switch}

Since the socket switch has lots of styles, when selecting the switch socket, consumers are vulnerable to personal preferences, which makes consumers buy some needless switch socket or makes switch socket not fully utilized, resulting in idle or porous switch socket or switch socket only use part of the hole, which is another waste.

\section{Residents in the course, because of quality problems} caused by waste receptacle switch replacement

E. Table 1 shows that $42.55 \%$ of respondents believe that in order to reduce costs, the developers use low-price and low-quality electrical equipment, which leads to the residents replacing the switch sockets again. $21.9 \%$ of respondents believe that in order to make home beautiful, the household replace switch sockets, resulting in a waste receptacle. $28.8 \%$ 
of respondents believe that their quality is not good for electrical equipment, damage caused by the waste needs to be replaced in the socket switch decoration. Developers should focus on social and environmental benefits besides making profits. Developers should use high-quality switches and sockets, which reduces the frequency of replacement tenants, thus contributing to the protection of resource conservation and the environment. Tenants should raise environmental awareness, and also pay attention to the protection of resource conservation and ecological environment. $59.8 \%$ of respondents accept that government advocates reducing home decoration switch sockets waste, $22.9 \%$ of respondents do not accept the government's advocacy. Government efforts to reduce waste outlet switch will have some resistance, the government should take measures to encourage people to reduce waste outlet switch. People should improve resource conservation and environmental protection awareness, understand government policy, and subject to government administration.

\begin{tabular}{|c|c|c|c|}
\hline The variable name & State variable & frequency & The percentage \\
\hline \multirow{5}{*}{$\begin{array}{l}\text { What do you think is the } \\
\text { cause of waste in } \\
\text { domestic outfit, switch } \\
\text { socket }\end{array}$} & $\begin{array}{l}\text { Developers to reduce cost, } \\
\text { the use of electrical } \\
\text { equipment, low lead to } \\
\text { residents to change again }\end{array}$ & 221 & $42.55 \%$ \\
\hline & $\begin{array}{l}\text { The need of the family is } \\
\text { decorated, in order to } \\
\text { make the family } \\
\text { decoration is beautiful }\end{array}$ & 114 & $21.9 \%$ \\
\hline & $\begin{array}{l}\text { Electrical equipment itself } \\
\text { quality is bad, the damage } \\
\text { need to change }\end{array}$ & 150 & $28.8 \%$ \\
\hline & other & 35 & $6.7 \%$ \\
\hline & A combined & 520 & $100.0 \%$ \\
\hline \multirow{4}{*}{$\begin{array}{l}\text { If the government } \\
\text { advocated to reduce the } \\
\text { replacement of family is } \\
\text { decorated in, switch } \\
\text { socket, your attitude }\end{array}$} & accept & 311 & $59.8 \%$ \\
\hline & Don't accept & 119 & $22.9 \%$ \\
\hline & unclear & 90 & $17.3 \%$ \\
\hline & A combined & 520 & 100.0 \\
\hline
\end{tabular}

F. The waste of discarding some switch socket which

can be reused.

\begin{tabular}{llll}
\hline The variable name & State variable & frequency & The percentage \\
\hline & Directly to throw away & 422 & $81.1 \%$ \\
How do you handle & Storage at home, for use & 38 & $7.3 \%$ \\
replacement socket and & when needed & & \\
switch & other & 60 & $11.5 \%$ \\
& A combined & 520 & 100.0 \\
Whether or not you will & yes & 215 & $41.3 \%$ \\
be abandoned sockets, & no & 305 & $58.7 \%$ \\
switches and other & A combined & 520 & $100.0 \%$ \\
garbage classification & & & \\
processing & & & \\
\hline
\end{tabular}


Table 2 shows that $81.1 \%$ of the surveyed directly throw the replaced switch socket, $7.3 \%$ chose keeping

the replacement of switch socket and storage at home, in case they need. Throwing the replacement of switch socket not only causes a waste of resources, but also increases people's expense. Keeping the switch sockets spare is conducive to saving money, in addition it helps save resources. From the respondents directly throwing away the replacement of switches and sockets, $41.3 \%$ of people would waste outlet switch with other waste classification, $58.7 \%$ of people will not switch, socket classification. Therefore, many people have a weak sense of classification consciousness. Throwing away the socket switch together with other rubbish, is not conducive to the socket switch recycling, but also damage the environment.

\section{THE RESULTING WASTE REASONS}

\section{A. People lack of the awareness of the home}

improvement outlet switch.

When it comes to home appliances, it is hard to think of switch socket, but the socket switch is indeed an appliance. According to the definition of appliances, socket switch is visible appliances. But compared to other types of home appliances, socket switch apparently unremarkable, the value of wasting a switch socket is smaller than other appliances. And switch socket has lower prices, the head of household is not included in the decoration of the main consideration list, it is difficult to attract attention. So when you install or replace the socket, you may not consider it a waste problem. Although switch socket is modest, in modern buildings it is essential. It can be said that as long as the laying of a modern building on the circuit is not a landmark reform or innovation, it is inseparable from the switch socket. Thus switch socket is very important, the demand is very great. Demand is considered waste from a large sense. But as long as this switch socket misunderstanding persists, the waste of switch socket would be difficult to contain. The original device was changed into habits of most people when decorating, after some people to buy homes, being overly critical or too much the pursuit of personalized, original slightly dissatisfied with electrical equipment, then do the second renovation, resulting in significant waste.(Xiaoxiang, 2006)

\section{B. Developers blindly seek benefits for the purpose of economic, and often neglect the ecological and social benefits.}

Although the concept of energy saving gradually become a human consensus, more and more people are getting more and more accepted environmental awareness and low-carbon lifestyle, but this does not go deep into switch socket areas, which means that people ignore the switch socket when consider energy conservation. This can be seen in two ways: First, there is not much research about the waste outlet switch, the literature on the switch socket wasted is very little; Second, questionnaire analysis from our research group recovered the following results.

People think switch socket waste problem in home decoration is not very serious, it is easy to overlook the switch socket waste problem. Thereby increasing awareness of environmental protection is of great significance to solve switch socket waste problem. At present, conservation awareness of switch socket needs to be improved.

\section{Decoration designers are not professional}

Interior design companies, decoration designers mostly fine arts, architecture. There are few professional lighting designers. Many designers in order to achieve visual effects, design lamps bit more complex, resulting in a lot of wasted electricity. Some designers in order to improve cost, tends to encourage consumers to gain entry in the decoration, which leads to a lot of waste. "The ' guerrilla ' enterprise market disruption. Most consumers think, ' guerrilla ' decoration craft fair, and affordable, way more flexible. "(Jian Sun, 2006)" with the escalating competition in the market of furniture decoration market industry, all sorts of decorative materials store, urban and rural construction teams are still emerging, even there are a variety of rules does not speak of their companies in the industry "(Li Yuanlin, 2007) without formal decoration companies tend to cause a lot of unnecessary waste.

\section{Policies and laws}

In China, on the policy of home appliances cannot enumerate the hundreds, and specifically to the provinces. The "home appliances to the countryside", for example, we find in the different regions, "countryside" appliances vary. The money to support this policy is very great. But look at the policy history of home appliances, we could not find a socket-related, rather than grazing is extremely rare; and at horizontal view of all aspects of the policy of home appliances involved, we do not see the figure of the socket. The relevant legal and home appliances, the best known of the "People's Republic of China Product Quality Law" and the "People's Republic of China Consumer Protection Law" does not make the relevant provisions of the switch socket. Visibly, the switch socket object caused a huge waste of resources and energy has not been paying attention to the relevant departments and the public, but was ignored. Also, policy makers ignore the seriousness of the waste receptacle. And in today's society, people are in general disregard outlet waste problem, so that the switch socket waste problem cannot be solved from the top to the bottom nicely. Because the switch socket is in the blind spot on the policies and laws, even though it found that the severity of waste is difficult through the existing regulations for its effective management and norms. And because the switch socket is in the blind spot on the policies and laws, waste receptacle was difficult issues into the public eye. 


\section{E. The level of technology constraints}

According to statistics, up to tens of billions each year and continuing to improve market has attracted thousands of companies to join the Electrical Manufacturing. There are more than 2,000 electrical enterprises in the domestic production of switches. Because of the enormous differences in the level of consumption in China, well-known brands accounted for only $20 \%$ of the market share, and the remaining $80 \%$ of the market is still all kinds of small businesses occupying. When many consumers select switches and sockets, electrical safety and home safety is the first line of defense, so the choice of switches and sockets must not be careless when it does not take into account the selected outlet meets the requirements of energy conservation. Manufacturing outlets belong to the category of light industry. Our light industry has reached a certain size, even as the "world factory", its scientific and technological content need to be improved. Under the trend of energy saving, it is only a matter of time to recognize that the problem, but if there is no "hardware support" and the policy of saving socket, even recognizing the problem, we cannot solve it. The Technology Innovation in China is relatively weak in this area, so the waste outlet became very hard to solve.

\section{III.THE SOLUTION TO THIS WASTE OF SIGNIFICANCE}

\section{A. Conceptual change}

It is important to improve people's consumption concept, so that the whole community will have a clear understanding switch socket waste during the decoration.

\section{B. Establish a resource-saving and \\ environment-friendly society}

The survey research from being overlooked for house decoration carried wastage of electrical equipment research, not only helps to reduce the cost of energy production, while reducing the production, transportation, sales process, pollution of the environment, in line with ecological civilization spirit. The issue advocate ecological consumption patterns, help raise environmental awareness, and the ability to reverse the trend of environmental degradation from the source to the establishment of environment-friendly society;

\section{The real implementation of energy conservation}

From reality and practical curb waste, we must reduce environmental pollution. By studying this project, you can find the appropriate solutions to make reasonable suggestions, help from reality and practical curb waste. Eco-homes is one of the home improvement trend in the future, "eco-homes tend to be more on the function of the original state and the State of nature" (Sun Bingming, 2006) ecological residences in solve home electrical waste problem has a natural advantage. Therefore, decoration ideas home decoration by changing the electrical equipment is of great significance to solve waste problems.

\section{REFERENCES}

[1] Huang xiaopo, analysis of household plugs, product quality supervision and inspection Institute in Wuhu, Wuhu, Anhui Province, 241002, Journal of Wuhu professional technology College, the English JOURNAL OF WUHU PROFESSIONAL TECHNOLOGY COLLEGE,2003,5 (2)

[2] Zou Hua, research and application of green design in household appliances, Guangdong University of technology, dissertation: http://d.wanfangdata.com.cn/Thesis_Y2097659.aspx

[3] Lian Hongfang, Su qingping, Wang mohui, Deng Tian long, Zhang Yong, Tang Guohu, technology of used electrical household appliance recycling and disposal, (School of material and bioengineering Chengdu University, Chengdu 610059, environmental pollution and its prevention, 2004,26 (1)

[4] the city. To be renovated first class decoration quality guaranteed--remember the basis is clearly preferred building material decoration market [j]. China economic information 2000,10:48-49.

[5] xiaoxiang. Changsha home improvements a waste of about 50 million dollars per year [n]. the China building materials news, 2006/08/08001.

[6] Jian Sun. long way home decoration "repairable" far [j]. the mass standardization. 2006 (06)

[7] Li Yuanlin. Reflections on some problems of modern home interior design [j]. Art panorama. 2007 (05)

[8] Sun Bingming. Ecological environment and home furnishings discussion on the reform of modern home decor [j]. Art education. $2006(01)$ 